\title{
Population reductions of Strongylocentrotus droebachiensis (Echinodermata) in Norway and the distribution of its endoparasite Echinomermella matsi (Nematoda)
}

\author{
A. Skadsheim, H. Christie, H. P. Leinaas \\ Norwegian Institute for Nature Research (NINA), Box 1037 Blindern, N-0315 Oslo, Norway
}

\begin{abstract}
ABSTRA.CT: Observations of sea urchin Strongylocentrotus droebachiensis (O. F. Müller) mass mortality at Vega island in mid Norway, and reduced sea urchin density in another area $280 \mathrm{~km}$ (aerial line) to the south, initiated a more extensive survey of sea urchin and kelp Laminaria hyperborea (Gunn.) Foslie forest distribution along $700 \mathrm{~km}$ of coastline. Records of the distribution and prevalence of the nematode Echinomermella matsi Jones \& Hagen, 1987, an endoparasite of S. droebachiensis, were also included as the parasite has been postulated to cause sea urchin mass mortality. Sampling was concentrated in 5 areas of coastline along mid and northern Norway. Each area was studied along a wave exposure gradient. Old kelp forests have persisted along the outermost exposed parts of the coastline despite the $20 \mathrm{yr}$ population outbreak of sea urchins. Inshore of the exposed kelp zone and towards the mainland, sea urchin dominated barren grounds still persisted. The distribution and abundance of $S$. droebachiensis in the southernmost area (Froya) was greatly reduced, and expansion of kelp into former barren grounds resulted. Reduced numbers of sea urchins and some macroalgal regrowth also occurred in the 2 central areas 140 and $280 \mathrm{~km}$ north of Froya, whilst high population densities of small sized S. droebachiensis on 'barrens' still dominated the inner zone in the 2 northern areas. The study indicated that $S$. droebachiensis populations, and hence the barren ground state, may be in a labile phase along the southern $300 \mathrm{~km}$ of the coast, whilst its state in the northern areas seems more persistent thus far. E. matsi was not found in the southernmost area. S. droebachiensis was heavily infested in the 2 central areas. In northern areas E. matsi was found only at a few sites. The pattern of parasite occurrence and sea urchin regression makes the role of $E$. matsi in this process questionable and indicates that 1 or more unidentified waterborne agents have been involved.
\end{abstract}

KEY WORDS: Laminaria hyperborea Strongylocentrotus droebachiensis Sea urchin mortalıty Kelp revegetation. Sea urchin parasite Norway

\section{INTRODUCTION}

For more than $20 \mathrm{yr}$ high densities of the green sea urchin Strongylocentrotus droebachiensis (O. F. Müller) have reduced formerly luxuriant and highly productive kelp Laminaria hyperborea (Gunn.) Foslie forests to barren grounds of low productivity, sensu Pearse et al. (1970), along the Norwegian coast between $63^{\circ} \mathrm{N}$ and $71^{\circ} \mathrm{N}$ (Sivertsen 1982, Hagen 1983, 1987, Skadsheim et al. 1993). Large parts of the shallow coastal zone, which is up to $50 \mathrm{~km}$ wide, have been denuded, but kelp forests still persist on the outermost, wave-exposed areas. The size of the overgrazed area implies that this is among the largest sea urchin outbreaks reported. Both as a general ecological and as an environmental problem, it is important to understand the patterns of persistence of the kelp and barren states and the patterns of sea urchin mortality that may lead to kelp forest restoration.

Similar large scale outbreaks of Strongylocentrotus droebachiensis have been studied extensively in the northwestern Atlantic (Mann 1977, Scheibling 1986, 1988, Pringle 1986, Johnson \& Mann 1988, Elner \& Vadas 1990, Scheibling \& Raymond 1990). There, a 
severe sea urchin mortality, caused by an endoparasitic amoebae (Jones \& Scheibling 1985), occurred over large areas some 10 to $15 \mathrm{yr}$ after sea urchins had created barren grounds. The epizootic mortality, sensu Kinne (1980, p. 15), was then followed by a rapid restoration of kelp forests (Miller \& Colodey 1983. Moore \& Miller 1983, Scheibling 1984, 1986, Scheibling \& Stephenson 1984, Miller 1985). These events were most pronounced on the east coast of Nova Scotia, Canada, while sea urchin dominated barren grounds remained further south and north (Pringle 1986, Keats 1991).

In early summer 1991, we observed a dramatic decline in numbers of Strongylocentrotus droebachiensis around several skerries in a barren area at Vega island in mid Norway (see Fig. 1) (H. Christie, H. P. Leinaas \& A. Skadsheim unpubl.). Here we had studied sea urchins since 1988 without observing any marked perturbation in population densities until this event. The degree of sea urchin mortality varied considerably between skerries, ranging from small reductions restored within a few months, to near elimination of local populations with a subsequent establishment of kelp vegetation. Moreover, in 1990 we observed kelp regrowth (Røv et al. 1990) on a former barren ground (Sivertsen 1982) at Froya island, $280 \mathrm{~km}$ south of Vega. These observations motivated us to carry out a survey on occurrence and population characteristics of kelps and sea urchins along $700 \mathrm{~km}$ of coastline (see Fig. 1) to search for evidence of reduced sea urchin populations outside the Vega area and possible regional trends in the phenomenon.

The survey covered the main area of extensive barren grounds created during the sea urchin outbreak in the 1970s. Less extensive barrens have been reported further to the north, past the northern tip of Norway (Sivertsen \& Wentzel-Larsen 1989), while the Frøya area west of Trondheim city is in the southernmost area where barren grounds have been observed (Sivertsen 1982). Most of this coastline had been surveyed by Sivertsen (1982), whose estimates of distribution and abundance patterns of sea urchins and kelp forest destruction facilitated assessments of large-scale changes during the last 10 years.

The population crash of Strongylocentrotus droebachiensis in Nova Scotia is the only case where the causal mechanism of sea urchin mass mortalty due to disease has been identified (Jones \& Scheibling 1985, Jangoux 1987a, b, c, Peters 1993). In the Caribbean Sea the speed and direction of the spreading of a mass mortality incident exclusively affecting the black sea urchin Diadema antillarum Philippi indicated the involvement of a water-borne pathogen (Lessios et al. 1983, 1984). However, neither in this case (Bauer \& Agerter 1987, 1994, Lessios 1988), nor in other instances of more small-scale sea urchin die offs where diseases have been suspected (Johnson 1971, Pearse et al. 1977, Pearse \& Hines 1979, Boudouresque et al. 1980, Maes \& Jangoux 1984, Williams et al. 1991, Dayton et al. 1992), have the pathogens been identified.

All sea urchin populations in the Vega area were infested by the parasitic nematode Echinomermella matsi Jones \& Hagen 1987 (Stien 1993, Christie et al. unpubl.) which Hagen (1992) suggested could cause mass mortality of Strongylocentrotus droebachiensis and thus terminate the barren ground state. Heavy infections of $E$. matsi have been reported from several places in northern Norway, the area from which this nematode was described (Jones \& Hagen 1987). So far, however, its distribution along the coast has been poorly described, and we therefore included records of parasite prevalence in all sea urchin populations investigated.

\section{METHODS}

Sampling was carried out in June 1992, in 5 areas: Frøya, Vikna, Vega, Lofoten and Harstad (Fig. 1). In each area we selected 3 localities from west to east with

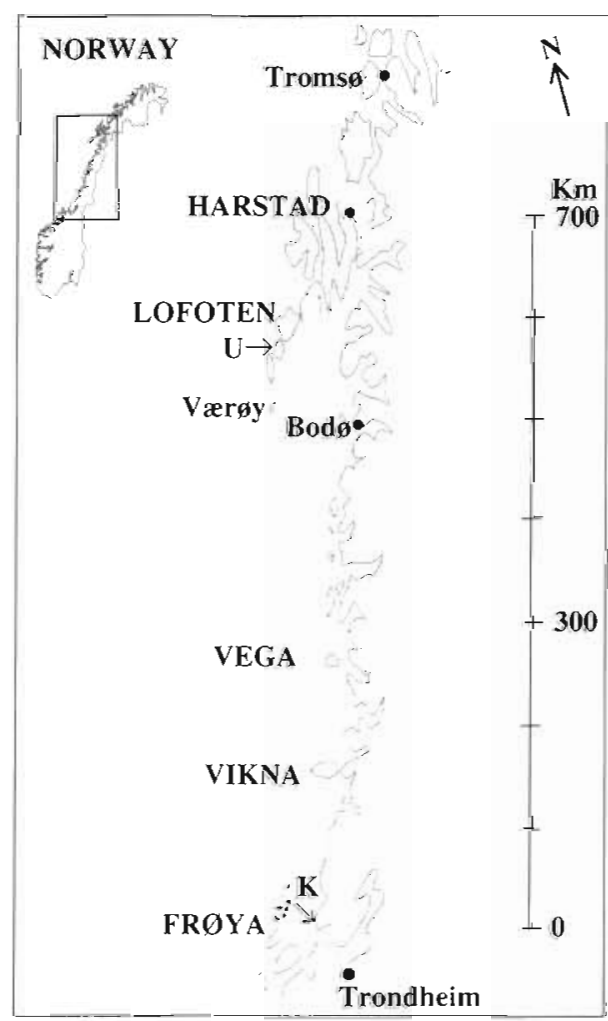

Fig. 1. Norway, showing the coastline with study areas (shaded). Arrows: extra sites (K: Kjeungskjæret; U: Utakleiv) 
decreasing wave exposure. One locality was selected in the outer kelp forest. The other 2 were chosen so that the middle locality would represent the outer part of the zone of previous kelp forest destruction, while the inner locality was well inside the main barren ground described by Sivertsen (1982). We sampled 3 sites within each locality, except for Vega where 2 sites were sampled at the middle locality and 4 sites were sampled at the inner locality. Distances between areas were $100 \mathrm{~km}$ or more, localities were 3 to $20 \mathrm{~km}$ apart, whilst most sites were 200 to $700 \mathrm{~m}$ apart. We selected sloping rock walls at all sites to reduce variance due to topography and substrate. Accessibility was also important because the sites were intended to be used for long-term monitoring. Some sites were included because they had been sampled in earlier studies.

Population studies of the dominant kelp Laminaria hyperborea were done by sampling plants in 4 haphazardly placed frames $\left(1 \times 1 \mathrm{~m}^{2}\right)$ at $5 \mathrm{~m}$ depth. The stipe length of each plant in the canopy layer was measured and age was determined by growth ring analyses (Kain 1963). The same sampling was not done at Vega, where a demographic analysis of $L$. hyperborea already existed (Sjøtun et al. 1993). However, we present an age distribution based on plants that were collected for a study of the hapteron fauna since it agreed with the one obtained by Sjøtun et al. (1993) and thus seems respresentative for the area. The longevity of $L$. hyperborea in Norway, up to about $20 \mathrm{yr}$, together with the feasibility of demographic analyses of the species (Kain 1963, 1971), made it possible to estimate when kelp recovery began after populations of sea urchins were reduced on former barren grounds.

Sea urchin Strongylocentrotus droebachiensis densities were estimated by counting in frames $\left(0.5 \times 0.5 \mathrm{~m}^{2}\right)$ placed haphazardly 10 times on each of the depths 2,5 and $10 \mathrm{~m}$. At each site, ca 100 sea urchins were collected randomly at $5 \mathrm{~m}$ depth for measurement of diameter (by vernier calipers) and assessment of parasite Echinomermella matsi prevalence (by dissection). For comparative purposes, 100 sea urchins were collected at 3 additional sites, Håskjæra at Frøya (Fig. 2), Kjeungskjæret between Frøya and Vikna, and Utakleiv west of our study area in Lofoten (Fig. 1). Sea urchin density was recorded only at Håskjæera, whilst test diameters and parasite prevalence were measured at all 3 sites. We had sampled at Hâskjæra in 1990 (Røv et al. 1990) and therefore could document changes which had occurred during the subsequent $2 \mathrm{yr}$.

At Frøya, we chose the northern tip of Frøya as the middle locality, and the bay south of Dyrviksundet, on the east side of Frøya, was chosen as the inner locality. Due to the discovery of an apparently ongoing process of kelp recovery following sea urchin regression at Frøya, we also included an extra inner locality (Leksa),

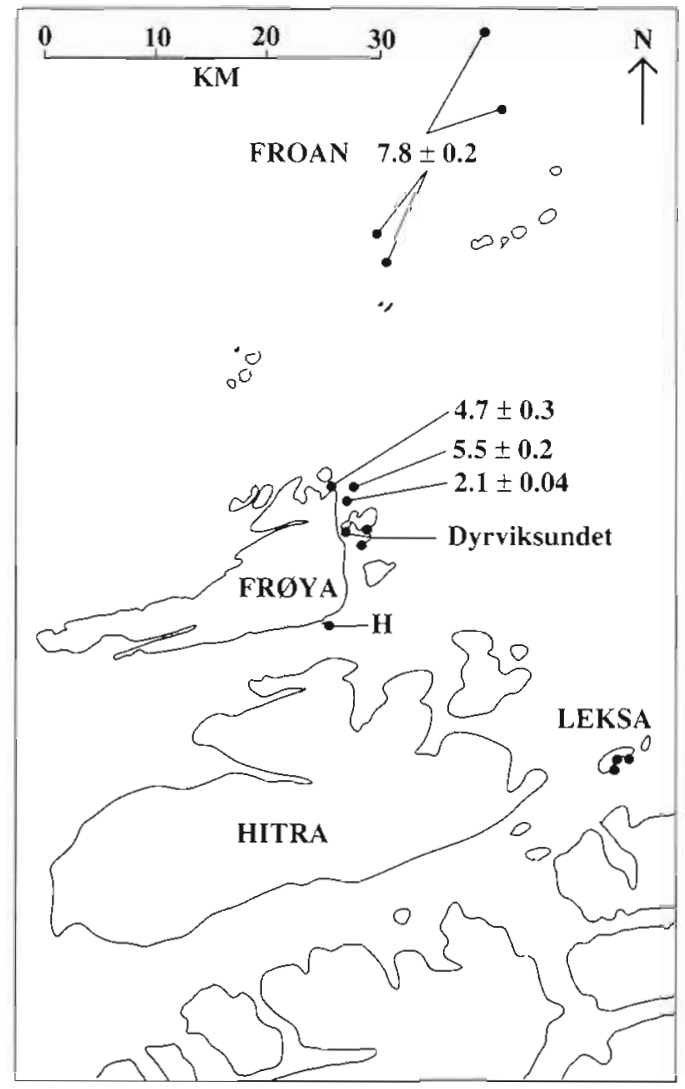

Fig. 2. The Froya area. Dots show positions of sites. Values are mean age \pm SE of kelp Laminaria hyperborea plants forming the canopy layer in the Froan archipelago and at the 3 sites on the revegetated locality near Frøya. H: Håskjæra. Positions of 3 sites just southeast of Dyrviksundet are also shown

closer to the mainland (Fig. 2). In addition, we also observed the occurrence of macroalgae and sea urchins across a transition zone from the kelp forest into the barren zone. These observations were made by looking through diving masks from a rubber boat or by short dives when organisms were difficult to see from the boat. The outer ungrazed kelp forest of this area was analysed at 4 sites in the Froan archipelago just north of Frøya in September 1993.

Density estimates and size frequency analyses of sea urchins were made on the data from the middle and inner localities in each area for comparison between areas. Thus, on Frøya the additional sites at Leksa and Håskjæra were used to trace trends in numbers of sea urchins in this area, but they were not included in the statistical analyses for comparison between areas.

Prior to statistical testing, data on kelp age and sea urchin diameter were square root transformed, whilst the density records were $\log (n+1)$-transformed. These transformations were found sufficient to homogenize the variances (Snedecor \& Cochran 1981). Differences for kelp age between areas were tested by 1-way 


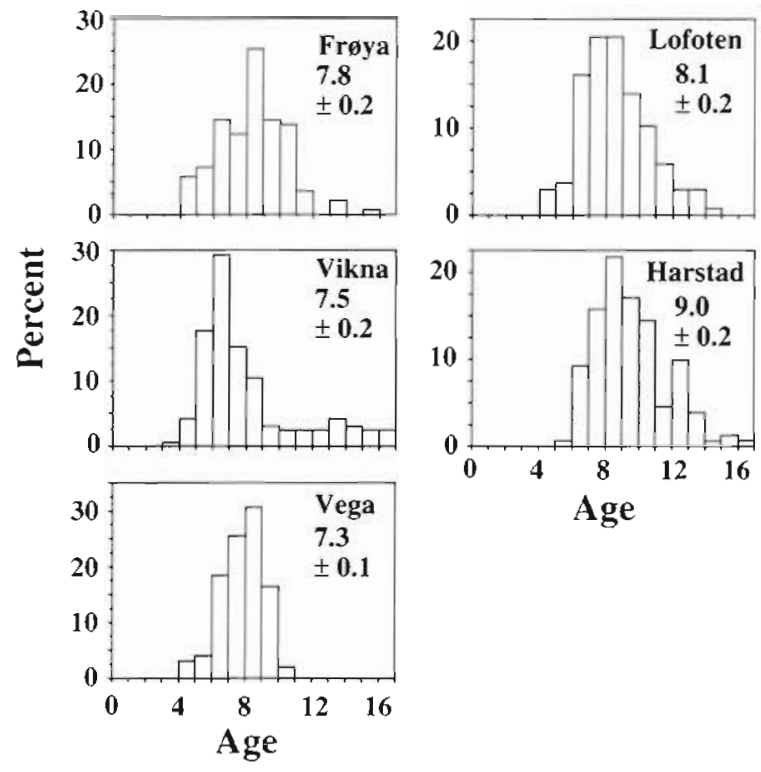

Fig. 3. Laminaria hyperborea. Age distribution of kelp plants forming the canopy layer in the 5 areas. Mean age $\pm \mathrm{SE}$ are shown

analysis of variance (ANOVA) and differences between means at sites or areas were tested by Fisher's Protected Least Significant Difference (Fisher's PLSD). All $t$-tests were performed as ungrouped comparisons. Kelp age and size measurements from the Vega area were omitted from the statistical comparisons since the kelp data were not collected by the same method as elsewhere and because emphasis was on comparing northern and southern areas.

Differences between density measurements of Strongylocentrotus droebachiensis were tested by a nested 4-way ANOVA with a mixed model. The fixed variables were area, locality and depth. Site was nested within locality and area. The analyses were done using the SAS GLM procedure (Freund et al. 1986). Differences in densities between areas were compared by Scheffé's test. Vega was not included in this test, as the main purpose was to describe and compare the state (sea urchin density) of the 2 southern and the 2 northern areas. Through our long-term studies in Vega we had already documented a very patchy mortality there (Christie et al. unpubl.). For the other 4 areas, we used the 2 previously chosen localities per area in the originally overgrazed zone, keeping the 3 sites at each locality to maintain a balanced design in the 4-way ANOVA. We thus excluded the outer kelp localities with no sea urchins and the additional localities mentioned above because they were chosen ad hoc to document the ongoing process at Froya and parasite prevalence. The 4-way ANOVA was not completely balanced because shallows prevented density counts at $10 \mathrm{~m}$ depth at some sites.

\section{RESULTS}

\section{Kelp along the coast}

At all outer localities there were intact kelp Laminaria hyperborea forests free of green sea urchins Strongylocentrotus droebachiensis. The canopy layer was largely dominated by 6 to 12 yr old plants with a few reaching $15 \mathrm{yr}$ or more. The age distribution of kelps in the various areas is shown in Fig. 3. The kelps in the southern areas (Frøya and Vikna) were significantly younger than those in the northern areas (Lofoten and Harstad); $t=5.03$ and $p<0.0001$ when kelp age records from Frøya and Vikna were pooled and compared to the pooled sample of Lofoten and Harstad. Excluding Vega, the mean kelp ages of the 4 areas, except for Frøya compared to Vikna and Lofoten respectively, were significantly different (Table 1). Our records (Fig. 3) and those of Sjøtun et al. (1993) indicate little variation in mean kelp age along the coast from Froya to Vega. The stipe lengths of kelps decreased to the north with lengths falling into 2 groups, Froya and Vikna versus Lofoten and Harstad (Table 2). The mean stipe length in each area was significantly different from the other 3 (Fisher's PLSD: $\mathrm{p}<0.0001)$.

Barrens with high densities of sea urchins covered wider zones in the more sheltered part of the coast closer to the mainland. Between the outer kelp forest and the barrens there were zones or patchy areas in transition states, either as kelp forests subjected to sea urchin grazing, or former barrens in different stages of macroalgal regrowth.

Table 1. Laminaria hyperborea. One-way ANOVA for the effect of area on square-root-transformed values of kelp age and Fisher's PLSD for the square root of age and the effect of area

\begin{tabular}{|c|c|c|c|c|c|c|}
\hline $\begin{array}{l}\text { ANOVA } \\
\text { Source }\end{array}$ & $\mathrm{df}$ & & $S S$ & MS & $F$ & $\mathrm{p}$ \\
\hline Kelp age & 3 & & 6.65 & 2.22 & 1.3 .31 & $<0.0001$ \\
\hline Error & 584 & & 7.27 & 0.17 & & \\
\hline \multicolumn{7}{|c|}{ Fisher's PLSD } \\
\hline \multicolumn{7}{|c|}{ Areas compared: } \\
\hline & $\begin{array}{l}\text { Froya- } \\
\text { Vikna }\end{array}$ & $\begin{array}{l}\text { Frøya- } \\
\text { Lofoten }\end{array}$ & $\begin{array}{l}\text { Frøya- } \\
\text { Harstad }\end{array}$ & $\begin{array}{l}\text { Vikna- } \\
\text { Lototen }\end{array}$ & $\begin{array}{l}\text { Vikna- } \\
\text { Harstad }\end{array}$ & $\begin{array}{l}\text { Lofoten- } \\
\text { Harstad }\end{array}$ \\
\hline p & 0.1040 & 0.3875 & $<0.0001$ & 0.0113 & $<0.0001$ & 0.0007 \\
\hline
\end{tabular}


Table 2. Laminaria hyperborea. One-way ANOVA for the effect of area on square-root-transformed values of stipe length in the 4 areas Froya, Vikna. Lofoten and Harstad and the mean values $(\mathrm{cm}) \pm \mathrm{SE}$ in the 4 areas

\begin{tabular}{|lrcccc|}
\hline $\begin{array}{l}\text { ANOVA } \\
\text { Source }\end{array}$ & df & SS & MS & F & p \\
\hline $\begin{array}{l}\text { Stipe length } \\
\text { Error }\end{array}$ & 3 & 982.48 & 327.49 & 221.17 & $<0.0001$ \\
$\begin{array}{l}\text { Stipe length } \\
\text { Froya }\end{array}$ & 846.97 & 1.48 & & \\
& Vikna & Lofoten & Harstad \\
\hline & $105.9 \pm 2.2$ & $121.9 \pm 2.0$ & $58.5 \pm 1.9$ & $80.8 \pm 1.4$ \\
\hline
\end{tabular}

largely occurred as scattered groups of small and young plants. Hence, the macroalgal cover appeared to be in a somewhat younger stage of recovery at Leksa compared to that at Dyrvik-sundet. The density of Strongylocentrotus droebachiensis at Leksa was somewhat higher than at Dyrviksundet (mean sea urchin densities \pm SE were $22.3 \pm 4.6,1.7 \pm 1.3$ and 0 specimens $m^{-2}$ at 2,5 and $10 \mathrm{~m}$ depth respectively), but the differences between the 2 localities were not significant at any depth $(t=0.568, \mathrm{p}=0.579$ at $2 \mathrm{~m}$ depth and $t=1.711, \mathrm{p}=0.092$ at $5 \mathrm{~m}$ depth).

\section{Kelp and sea urchins at Frøya}

At the northern tip of Frøya, the middle locality in this area (Fig. 2), a young to medium-aged forest of Laminaria hyperborea was established in an area where Sivertsen (1982) reported barren grounds. Mean ages of the canopy forming plants decreased from the most exposed site towards more sheltered ones to the west and southwest (Fig. 2). The decrease in age was significant (1-way ANOVA for the effect of site on age; $\mathrm{df}=2,135, \mathrm{SS}=21.612, \mathrm{MS}=10.806$, $F=182.987, \mathrm{p}<0.0001$ ) and all 3 mean kelp ages were significantly different (Fisher's PLSD; $p \leq 0.0005$ ). Observations along a $3 \mathrm{~km}$ line transect southwards from the locality at the northern tip of Frøya showed that $L$. hyperborea extended almost to the Dyrviksundet sound (Fig, 2). However, in this southern part of the transect the stands of $L$. hyperborea became more fragmented as they were replaced by the opportunistic Laminaria saccharina (L.) which dominated the innermost part of this kelp forest. We did not find Strongylocentrotus droebachiensis in the pure forest of $L$. hyperborea, but we saw scattered aggregations of large sea urchins among the $L$. saccharina stands in the inner (southern) part of the transect.

No kelp forest was present in the locality in the bay south of Dyrviksundet. There, the upper 2 to $3 \mathrm{~m}$ were barren, and below this depth were patches of variable sizes covered by mixed vegetation of annual brown algae, small recruits of Laminaria saccharina and some scattered large L. saccharina. Correspondingly, most sea urchins were aggregated at ca $2 \mathrm{~m}$ depth in this bay. Sea urchin densities (mean $\pm \mathrm{SE}$ ) were $14.3 \pm 4.0$, $4.3 \pm 2.1$ and 0 specimens $\mathrm{m}^{-2}$ at 2,5 and $10 \mathrm{~m}$ depth respectively. No $L$. hyperborea was found inward of Dyrviksundet.

On the Leksa locality closer to the mainland (Fig. 2), the situation resembled that in the bay south of Dyrviksundet. Sea urchins and barrens dominated the upper 2 to $3 \mathrm{~m}$. Below this zone ephemeral algae covered most of the bottom, while Laminaria saccharina
At the Håskjara site (Fig. 2) the bottom was barren in 1990. Annual algae mixed with scattered stands of small Laminaria saccharina dominated the substrate up to 2 or $3 \mathrm{~m}$ depth in 1992. The sea urchin density decreased in the same period (Fig. 4). The reduction was greatest at $5 \mathrm{~m}$ depth; the density was significantly lower $(t=4.70$, $p=0.0003$ ) in 1992 than in 1990. In fact, the relatively high sea urchin density at this depth, even in 1992 $\left(15.6 \pm 13.0\right.$ specimens $\left.\mathrm{m}^{-2}\right)$, compared to other sites in the Frøya area, was mainly due to a single quadrat in which one of the few remaining sea urchin aggregations was sampled. If this outlier is omittted, the mean density estimated from the remaining 9 replicates $\left(2.7 \pm 1.9 \mathrm{~m}^{-2}\right)$ indicate a $90 \%$ reduction $(t=6.08, p<0.0001)$ at this depth. Sea urchin density was also lower in 1992 than in
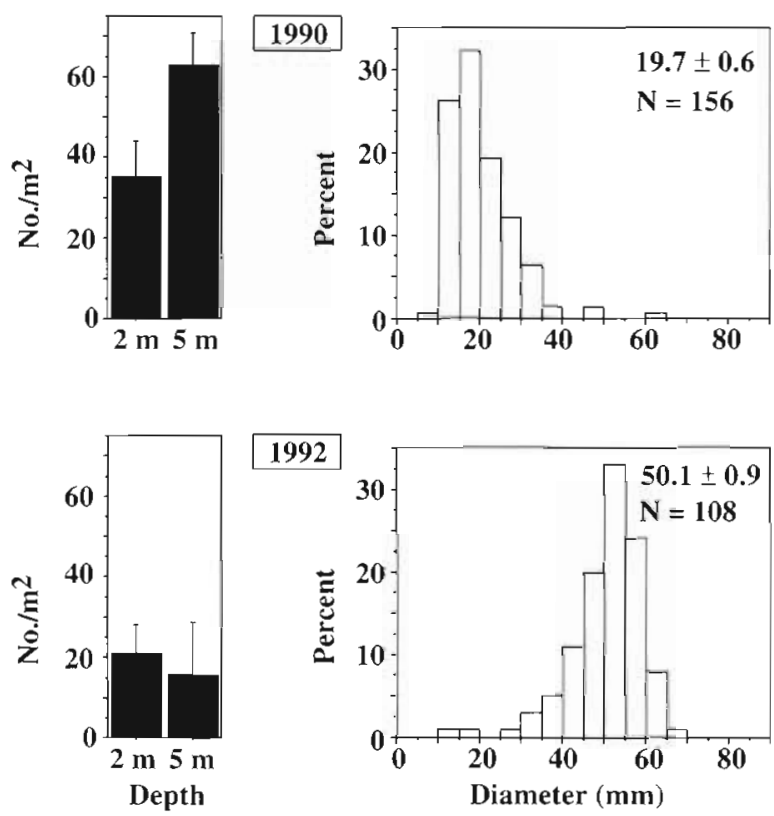

Fig. 4. Strongylocentrotus droebachiensis. Mean population density \pm SE at 2 and $5 \mathrm{~m}$ depth and size distribution of samples from $5 \mathrm{~m}$ depth at Håskjæra in 1990 and 1992. Mean test diameters $\pm \mathrm{SE}$ are shown 

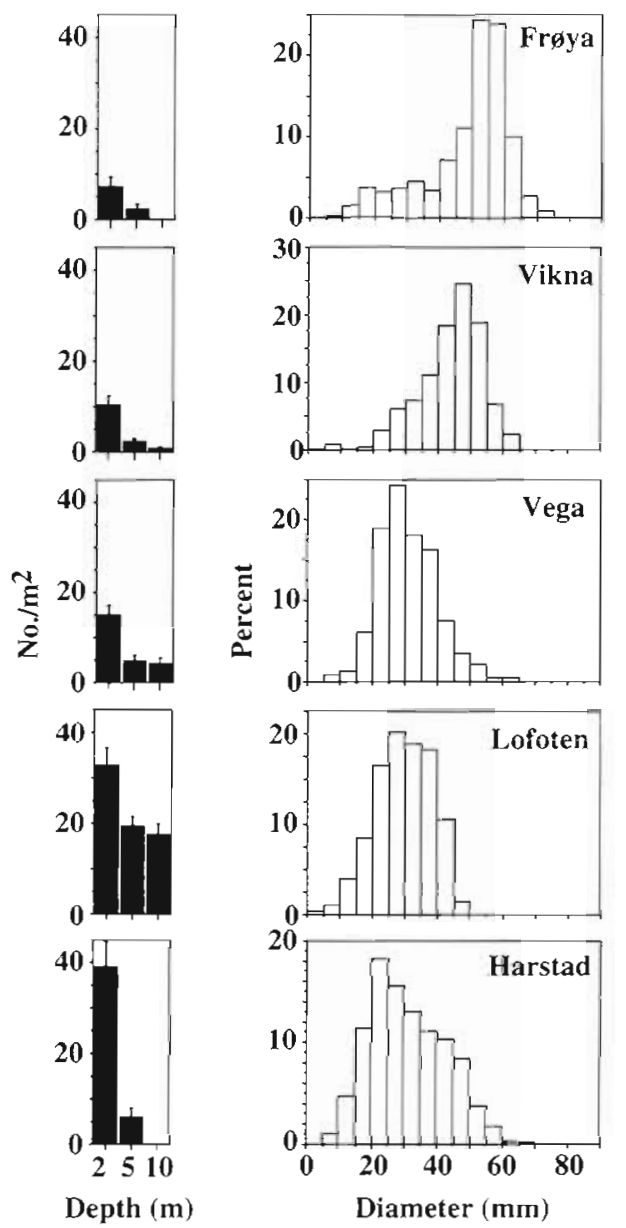

Fig. 5. Strongylocentrotus droebachiensis. Mean density \pm SE at 2, 5 and $10 \mathrm{~m}$ depth and size distribution in each area. Density estimates are based on 6 sites with 10 observations per site in each area, except for Vega where 4 sites were recorded. For sample sizes of diameter see Table 4

1990 at $2 \mathrm{~m}$ depth, but not significantly so $(t=1.26, \mathrm{p}=$ 0.223). If densities at 2 and $5 \mathrm{~m}$ depth at Håskjæra were pooled prior to testing and the outlier was included, then density was significantly lower in 1992 than in $1990(t=$ $4.29, \mathrm{p}<0.0001$ ). In the same period there was a strong increase in the mean test size of remaining sea urchins $(t=27.66, \mathrm{p}<0.0001)$ (Fig. 4$)$.

\section{Sea urchins along the coast}

The mean sea urchin densities of the pooled data from the middle and inner localities in the 5 areas are shown in Fig. 5. The mean sea urchin densities las $\log (n+1)]$ for the 2 southern and the 2 northern areas included in the 4-way nested ANOVA of density are shown in Table 3 . The interaction term area $x$ locality $x$ depth was not significant $(F=1.165, p=0.354$ ), and the interaction term area $\times$ locality was not significant $(F=$ $1.99, p=0.155$ ). These interaction terms were therefore not included in the model of the analysis. There were significant differences in sea urchin densities between depths; but, most importantly, the sea urchin densities in the 2 southern areas were distinctly lower than those in the 2 most northern areas (Table 3). There were, in addition, 2 significant interaction terms, area $x$ depth and locality $x$ depth, which were included in the ANOVA model. The contrast test (Scheffé's test) on differences between mean sea urchin densities in the 4 areas showed significant differences between means in all areas as well as a significant density reduction with depth (Table 3). In the south, the 2 areas Frøya and Vikna showed similar patterns of reduced sea urchin density, except that there were some urchins still present in what we have defined as the middle locality at Vikna. However, the great differ-

Table 3. Strongylocentrotus droebachiensis. ANOVA table for tests of $\log (n+1)$-transformed sea urchin densities on sites; see last part of 'Methods' Scheffé's test tested for differences between mean sea urchin density in areas following the nested ANOVA. CL: confidence limits. Diff. means: difference between means. $\log (n+1)$ of mean sea urchin density and SE in each area is included for the sake of comparison

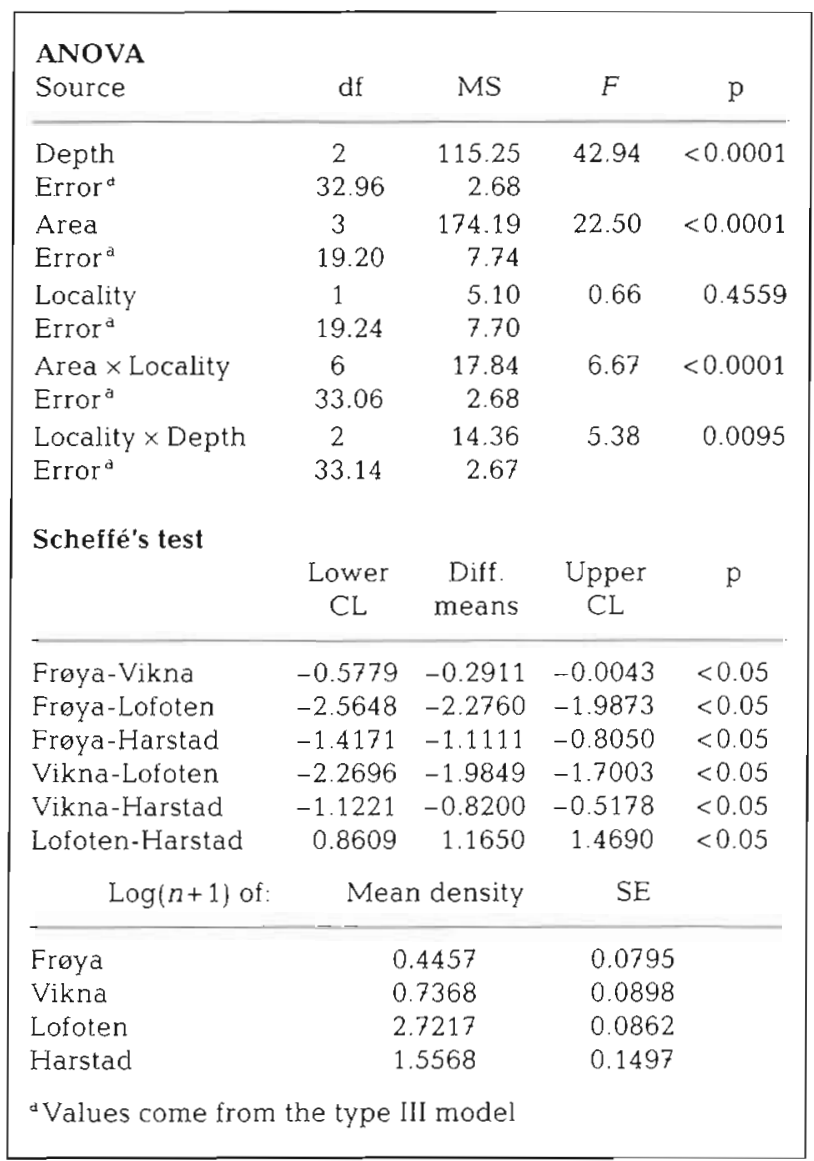


Table 4. Strongylocentrotus droebachiensis. One-way ANOVA for the effect of area on square-root-transformed measurements of sea urchin test diameter. Mean test diameter $(\mathrm{mm}) \pm \mathrm{SE}$ in each area. $\mathrm{N}$ : number of sea urchins measured in each area

\begin{tabular}{|c|c|c|c|c|c|}
\hline $\begin{array}{l}\text { ANOVA } \\
\text { Source }\end{array}$ & $\mathrm{df}$ & SS & MS & $F$ & $\mathrm{p}$ \\
\hline Diameter & 4 & 1261.49 & 315.37 & 342.84 & $<0.0001$ \\
\hline Error & 2820 & 2594.09 & 0.92 & & \\
\hline \multicolumn{6}{|c|}{ Test diameter } \\
\hline Area: & Froya & Vikna & Vega & Lofoten & Harstad \\
\hline Diameter & $48.2 \pm 0.5$ & $43.3 \pm 0.4$ & $30.3 \pm 0.6$ & $29.1 \pm 0.4$ & $30.7 \pm 1.2$ \\
\hline $\mathrm{N}$ & 719 & 621 & 227 & 628 & 630 \\
\hline
\end{tabular}

ence between the 2 areas was that all sites in the mid. dle and inner zones of Vikna were still barren, in spite of a very low sea urchin density. The 2 northern areas were characterized by high densities of sea urchins and extensive barrens.

The intermediately positioned Vega area (not included in the 4-way ANOVA; see 'Methods') clearly was in a transition state. It differed somewhat from the patterns observed further to the south. In the inner locality very patchy mass mortality had led to a variable sea urchin distribution pattern that, within short distances, ranged from local extinction and kelp recovery to sites with dense sea urchin populations on barren grounds (Christie et al. unpubl.). No algal revegetation on former barren grounds was seen in the Lofoten and Harstad areas. Remaining stands of kelp around Harstad were comprised of old plants.

The mean sea urchin test sizes in the 5 areas differed significantly (Table 4) (sea urchins from barrens at Vega were also included in this comparison). Mean test diameter decreased as sea urchin density increased (Fig. 4, Table 4). Mean test diameters were significantly different when most areas were compared by Fisher's PLSD (Table 5) following the 1-way ANOVA, except for diameters at Vega compared to those at Lofoten and Harstad respectively. Thus the 2 southern areas. Frøya and Vikna, contained mainly large sea urchins, compared to the 2 northern areas, Lofoten and Harstad, that contained small sea urchins.

\section{The parasite}

The endoparasitic nematode Echinomermella matsi was not found in sea urchins from the Frøya area or at Kjeungskjæret close to the mainland between Froya and Vikna. It was found at all sites at Vikna and Vega (Table 6) with a similar mean prevalence in the 2 areas. The prevalence of $E$. matsiranged from 12.4 to $43.3 \%$ at Vikna and from 18.2 to $53.3 \%$ at Vega. In Lofoten the parasite was not recorded at any of the 6 sites in the main study area. As E. matsi had been found at Værøy at the southwestern tip of Lofoten (Hagen 1983, 1987), we took an extra sample from Utakleiv (Fig. 1). At this site the prevalence of E. matsi was $13.6 \%$. The parasite was present at 3 of 7 sites around Harstad ( 5 to $20 \%$ prevalence).

\section{DISCUSSION}

Strongylocentrotus droebachiensis had not established dense populations in the outer, most exposed parts of the coast where kelp Laminaria hyperborea forests still persist. This agrees with Sivertsen (1982) who did not record barrens in this zone during a survey along the same coastline in 1981 . The demography of L. hyperborea in our outer localities, therefore, probably reflected mature kelp forests which are little affected by sea urchin grazing. The latitudinal trend in kelp demography with smaller size and increased age to the north was also recorded by Sjøtun et al. (1993). Temperature and light may thus be important factors affecting kelp growth, and kelp vulnerability to sea urchin grazing may, therefore, increase to the north.

The records of kelp distribution presented here and those of Sivertsen (1982), Røv et al. (1990), and Skadsheim \& Rinde (1995), show that Laminaria hyperborea persisted in a belt at all depths in the outer, most waveexposed coastal zone. The zone seems to represent a refugium from where kelp may increase its distribution landwards when populations of Strongylocentrotus droebachiensis on adjacent barren grounds decline. This zone differs from that described by Johnson \& Mann (1988). During the sea urchin outbreak in Nova

Table 5. Strongylocentrotus droebachiensis. Fisher's PLSD for the square root of sea urchin test diameter and the effect of area

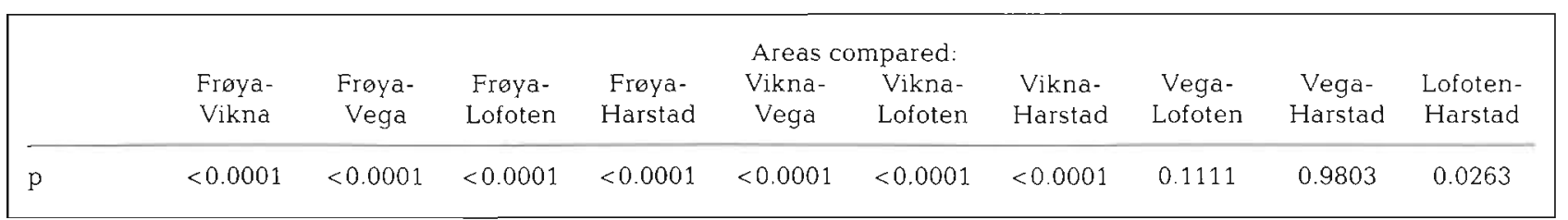


Table 6. Echinomermella matsi. Prevalence (\% of sea urchins infected) of the parasite in the different areas. No. of $S$. droebachiensis: number of $S$. droebachiensis examined. No. of sites: number of sites sampled in an area

\begin{tabular}{|lcccc|}
\hline Area & $\begin{array}{c}\% E \\
\text { matsi }\end{array}$ & $\begin{array}{c}\text { No. of S. droe- } \\
\text { bachiensis }\end{array}$ & $\begin{array}{c}\text { No. of } \\
\text { sites }\end{array}$ & $\begin{array}{c}\text { No. of sites } \\
\text { with E. matsi }\end{array}$ \\
\hline Froya & 0 & 719 & 7 & 0 \\
Vikna & 24.3 & 621 & 6 & 6 \\
Vega & 27.4 & 529 & 7 & 7 \\
Lofoten & 2.1 & 746 & 7 & 1 \\
Harstad & 4.2 & 669 & 7 & 3 \\
\hline
\end{tabular}

Scotia, Laminaria longicruris Pyl, maintained refuge populations in a narrow band confined to the low intertidal and shallow subtidal zones from where kelp recovery was rapid and widespread following the demise of the sea urchins.

In the Froya area, the kelp forest had advanced closer to the mainland compared to the state described by Sivertsen (1982). He reported extensive barren grounds and estimated sea urchin densities of about 70 specimens $\mathrm{m}^{-2}$ where we found 2 to 6 yr old kelp forests. In this locality, Laminaria hyperborea became younger with decreasing exposure and was finally replaced by more opportunistic species. This age and species cline might reflect the time the slowly dispersing, but competitively dominant, L. hyperborea needs to expand when an area becomes free of sea urchins. However, the observed gradient apparently also reflected a gradual sea urchin decline. At the Håskjæra site the change took place after 1990 (Røv et al. 1990), i.e. several years after the forest of $L$. hyperborea had become restablished on the northern tip of Frøya. Moreover, the early stage of macroalgal recovery at Leksa indicated a more recent reduction of numbers of sea urchin at this innermost locality. The general aggregation of Strongylocentrotus droebachiensis in the shallows and a density decline with increasing water depth in all areas comply with observations made elsewhere (Himmelman 1986) and with those of Sivertsen (1982).

The increase in mean sea urchin test size observed at Håskjæra is explicable in terms of improved foraging conditions for the remaining individuals after the density reductions. Specimens of ca $20 \mathrm{~mm}$ may increase their test diameter by 10 to $20 \mathrm{~mm} \mathrm{yr}^{-1}$ (Swan 1961, Larson et al. 1980), which would be equivalent to the changes observed at Håskjæra. Size-specific mortality, as observed for Diadema antillarum by Hunte et al. (1986), cannot explain the change in test size distribution between the 2 dates, because the dominant, large size classes of 1992 were hardly present in 1990 . Immigration from deeper waters is unlikely, because we saw only small sea urchins at $5 \mathrm{~m}$ and towards deeper waters in 1990.

Our study suggests that a gradual largescale decrease in density of Strongylocentrotus droebachiensis proceeds northwards. A distinct reduction in sea urchin densities occurred at Vikna too. Both barren ground localities lay within the barren ground zone where Sivertsen (1982) reported $S$. droebachiensis at $>70$ ind. $\mathrm{m}^{-2}$. Except for the upper $2 \mathrm{~m}$ at the inner locality, all Vikna sites showed sea urchin densities well below the level (ca 10 ind $\mathrm{m}^{-2}$ ) that induced macroalgal recovery at Vega (Christie et al. unpubl.). Prevailing barrens at Vikna in 1992 may reflect a recent population decline in the area. However, predominance of similarly large sized sea urchins at Vikna, as at Frøya, may indicate that a reduction in sea urchin density at Vikna occurred somewhat earlier than indicated by the still persisting barren ground.

Whether the patchy mortality observed at Vega will continue and eventually result in a general decline of sea urchin densities in this area is still unclear. Increased growth of opportunistic brown algae on several former barren grounds in 1992 to 1993, indicated continued decreases of sea urchin densities, while other barrens still persisted with high sea urchin densities at the end of 1993 at Vega (Christie et al. unpubl.). In the 2 northern areas, Lofoten and Harstad, our findings were more in accordance with those of Sivertsen (1982) and Hagen (1983, 1987), with no signs of sea urchin regression. These areas were dominated by small sea urchins, as observed at Håskjæera in 1990. Such a state characterizes barrens that have persisted for some years with high sea urchin densities (Lang \& Mann 1976, Johnson \& Mann 1982).

We found that the endoparasitic nematode Echinomermella matsi has a limited distribution compared to its host, Strongylocentrotus droebachiensis, which is widely distributed in the North Atlantic, the Barents Sea and the Northeast Pacific (Vasseur 1952, Jensen 1974, Propp 1977. Gagnon \& Gilkinson 1994). In contrast, the parasite has only been found in Norway, with a main range by 1992 from Vikna to Bodø and Værøy (Fig. 1), a distance of about $400 \mathrm{~km}$.

The present distribution of Echinomermella matsi might be of recent origin and related to the sea urchin outbreak in the 1970 s. The southern limit of E. matsi seems rather sharp, as sea urchin fishermen operating north of Frøya to about $50 \mathrm{~km}$ south of Vikna have not found the parasite (K. \& R. Svenning pers. comm.). In contrast, our northern records of scattered occurrences of E. matsi at low prevalence in the Lofoten and Harstad areas agree with observations of K. Sivertsen (pers. comm.) who found the parasite sparsely distrib- 
uted ca 10 to $20 \mathrm{~km}$ north of Tromsø. Such differences in southern and northern distribution limits might indicate dispersal along the northgoing Norwegian coastal current. In $1981 \mathrm{~K}$. Sivertsen (pers. comm.) found only a few parasitised sea urchins at Vega. Hagen (1992) reported increased parasite prevalence from 6 to $65 \%$ in $7.5 \mathrm{yr}$ at one site near Bodø. Falk-Petersen \& Lønning (1983) did not observe E. matsi in Strongylocentrotus droebachiensis at Tromsø, whilst K. Sivertsen (pers. comm.) observed it there more recently.

Hagen (1992) proposed that Echinomermella matsi could terminate population outbreaks of Strongylocentrotus droebachiensis. We have no evidence for such a mechanism at any locality of this study. The extensive population decline of $S$. droebachiensis in the Frøya area occurred south of the range of E. matsi. At Vega, a prevalence ranging from 25 to $60 \%$ between sites (Stien 1993) could hardly explain the up to $90 \%$ mortality observed on some skerries in 1991 (Christie et al. unpubl.). We do not, however, reject the possibility that heavy infection may lead to an increased host mortality. E. matsi affects $S$. droebachiensis by reducing its gonads (Hagen 1992, Skadsheim et al. 1993, Stien 1993), which function as a reproductive organ and as the primary energy storage organ (Stott 1931, Gonor 1973). However, the parasite has to grow quite large before gonad damage is observed (Stien 1993).

The large-scale pattern in sea urchin reduction may suggest involvement of a waterborne agent that has gradually proceeded northwards with the Norwegian coastal current. On a smaller scale $(\mathrm{km})$, such a mechanism might also explain the spatial distribution of mortality on Vega in 1991. There, the most heavily affected populations were found on skerries grouped along the direction of the water current through a sound (Christie et al. unpubl.). However, the trend of sea urchin mortality gradually expanding over large areas in the south might not necessarily represent the same phenomenon as the patchy mortality we have observed in the Vega area.

Mann (1977), Scheibling (1986, 1988), Elner \& Vadas (1990) and Scheibling \& Raymond (1990) discussed a possible cyclical alternation between kelp forests or sea urchin dominated barrens in the Northwestern Atlantic. There is no evidence for such a cyclicity along the Norwegian coastline. Long-term observations of local fishermen, who use the kelp forest as fishing grounds, suggest that the surveyed coastline was persistently dominated by kelp forests for generations (of fishermen) until the major sea urchin outbreak in the 1970s. Our observations indicate that the resulting barren state dominated by sea urchins may have an inherent instability. During the last years population reductions of sea uchins have led to large effects on algal growth and kelp recovery over large areas. This implies greatly improved foraging conditions and increased growth rate and gonad production among remaining sea urchins. We have not, however, observed that this has resulted in increased numbers of sea urchins and renewed high grazing pressure on reestablished kelp forest.

Acknowledgements. The survey was sponsored by The Norwegian Directorate for Nature Management. The Vega data collection and manuscript preparation was performed within the research programme MARE NOR, sponsored by the Norwegian Research Council and The Norwegian Institute for Nature Research (NINA). We thank E. Rinde and S. Nilsen for their great efforts during the field work, N. Yoccoz and R. A. Ims for statistical advice, and J. S. Gray and R. L. Vadas for valuable criticism.

\section{LITERATURE CITED}

Bauer, J. C., Agerter, C. J. (1987). Isolation of bacteria pathogenic for the sea urchin Diadema antillarum (Echinodermata: Echinoidea). Bull. mar. Sci. 40: 161-165

Bauer, J. C., Agerter, C. J. (1994). Isolation of potentially pathogenic bacterial flora from tropical sea urchins in selected West Atlantic and East Pacific sites. Bull. mar. Sci. 55: $142-150$

Boudouresque, Ch.-F., Nedelec, H., Shepherd, S. A. (1980). The decline of a population of the sea urchin Paracentrotus lividus in the bay of Port-Cros (Var, France). Trav. sci. Parc natl. Port-Cros 6: 243-251

Dayton, P. K., Tegner, M. J., Parnell, P. E., Edwards, P. B. (1992). Temporal and spatial patterns of disturbance and recovery in a kelp forest community. Ecol. Monogr. 62: $421-445$

Elner, R. W., Vadas, R. L. (1990). Inference in ecology: the sea urchin phenomenon in the northwestern Atlantic. Am. Nat. 136: 108-125

Falk-Petersen, I.-B, Lønning, S. (1983). Reproductive cycles of two closely related sea urchin species, Strongylocentrotus droebachiensis and Strongylocentrotus pallidus (G. O. Sars). Sarsia 68: 157-164

Freund, R. J., Littell, R. C., Spector, P. C. (1986). SAS system for linear models. SAS Institute, Cary, NC

Gagnon, J.-M., Gilkinson, K. D. (1994). Discrimination and distribution of the sea urchins Strongylocentrotus droebachiensis (O. F. Müller) and S. pallidus (G. O. Sars) in the Northwest A.tlantic. Sarsia 79: 1-11

Gonor, J. J. (1973). Reproductive cycles in Oregon populations of the echinoid, Strongylocentrotus purpuratus (Stimpson). 1. Annual gonad growth and ovarian gametogenetic cycles. J. exp. mar. Biol. Ecol. 12: 45-64

Hagen, N. T. (1983). Destructive grazing of kelp beds by sea urchins in Vestfjorden, Northern Norway. Sarsia 68: $177-190$

Hagen, N. T (1987). Sea urchin outbreaks and nematode epizootics in Vestfjorden, Northern Norway. Sarsia 72 : 213-229

Hagen, N. T (1992). Macroparasitic epizootic disease: a potential mechanism for the termination of sea urchin outbreaks in Northern Norway? Mar. Biol. 114: 469-478

Himmelman, J. H. (1986). Population biology of green sea urchins on rocky barrens. Mar. Ecol. Prog. Ser. 33: 295-306

Hunte, W., Côté, I., Tomascik, T (1986). On the dynamics of 
the mass mortality of Diadema antillarum in Barbados. Coral Reefs 4: 135-139

Jangoux, M. (1987a). Diseases of Echinodermata. I. Agents microorganisms and protistans. Dis. aquat. Org. 2: $147-162$

Jangoux, M. (1987b). Diseases of Echinodermata. II. Agents metazoans (Mesozoans to Bryozoa). Dis. aquat. Org. 2: $205-234$

Jangoux, M. (1987c). Diseases of Echinodermata. IIl. Agents metazoans (Annelida to Pisces). Dis. aquat. Org. 3: 59-83

Jensen, M. (1974). The Strongylocentrotidae (Echinoidea), a morphologic and systematic study. Sarsia 57: 113-158

Johnson, C. R., Mann, K. H. (1982). Adaptations of Strongylocentrotus droebachiensis for survival on barren grounds. In: Lawrence, J. M. (ed.) Echinoderms: proceedings of the International Conference, Tampa Bay. A. A. Balkema, Rotterdam, p. 277-283

Johnson, C. R., Mann, K. H. (1988). Diversity, patterns of adaptation, and stability of Nova Scotian kelp beds. Ecol. Monogr. 58: 129-154

Johnson, P. T. (1971). Studies on diseased sea urchins from point Loma. Kelp Habitat Improvement Project, Annual Report, 1970-1971. California Instute of Technology, Pasadena, p. 82-90

Jones, G. M., Hagen, N. T. (1987). Echinomermella matsi n. sp., an endoparasitic nematode from the sea urchin Strongylocentrotus droebachiensis in Northern Norway Sarsia 72: 203-212

Jones, G. M., Scheibling, R. E. (1985). Paramoeba sp. (Amoebida, Paramoebidae) as the possible causative agent of sea urchin mass mortality in Nova Scotia. J Parasitol. 71 $559-565$

Kain, J. M. (1963). Aspects of the biology of Laminaria hyperborea. Il. Age, weight and length. J. mar. biol. Ass. U.K. 43: $129-151$

Kain, J. M. (1971). Synopsis of biological data on Laminaria hyperborea. F.A.O. Fish. Synopses 87: 1-69

Keats, D. W. (1991). Refugial Laminaria abundance and reduction in urchin grazing in communities in the NorthWest Atlantic. J. mar. biol. Ass. U.K. $71: 867-876$

Kinne, O. (1980). Diseases of marine animals, General aspects, Protozoa to Gastropoda. Vol. 1. Wiley, Chichester

Lang, C., Mann, K. H. (1976). Changes in sea urchin populations after the destruction of kelp beds. Mar Biol. 36: $321-326$

Larson, B. R., Vadas R. L., Keser, K. (1980). Feeding and nutritional ecology of the sea urchin Strongylocentrotus droebachiensis in Maine, USA. Mar. Biol. 59: 49-62

Lessios, H. A. (1988). Mass mortality of Diadema antillarum in the Caribbean: What have we learned? A. Rev. Ecol. Syst. 19: $371-393$

Lessios, H. A., Glynn, P. W., Robertson, D. R. (1983). Mass mortalities of coral reef organisms. Science 222:715

Lessios, H. A., Robertson, D. R., Cubit, J. D. (1984). Spread of Diadema mass mortality through the Caribbean. Science 226: $335-337$

Maes, P., Jangoux, M. (1984). The bald-sea-urchin disease: a bacterial infection. In: Keegan, B. F., O'Connor, B. D. S (eds.) Echinoderms: proceedings of the Fifth International Echinoderm Conference, Galway. A. A. Balkema, Rotterdam, p. 331-334

Mann, K. H. (1977). Destruction of kelp-beds by sea-urchins: a cyclical phenomenon or irreversible degradation? I lelgolander wiss. Meeresunters. 30: 455-467

Miller, R. J. (1985). Succession in sea urchin and seaweed abundance in Nova Scotia, Canada. Mar. Bıol. 84: $275-286$
Miller, R. J., Colodey, A. G. (1983). Widespread mass mortalities of the green sea urchin in Nova Scotia, Canada. Mar. Biol. 73: 263-267

Moore, D. S., Miller, R. J. (1983). Recovery of macroalgae following widespread sea urchin mass mortality with a description of the nearshore hard-bottom habitat on the Atlantic coast of Nova Scotia. Can. Tech. Rep. Fish. Aquat. Sci. 1230

Pearse, J. S., Clark, M. E., Leighton, D. L., Mitchell, C. T., North, W. J. (1970). Final report. Marine waste disposal and sea urchin ecology. In: North, W. J. (ed.) Kelp habitat improvement project, annual report (1 July 1969-30 June 1970), Appendix. California Institute of Technology, Pasadena, p. 1-93

Pearse, J. S., Costa, D. P., Yellin, M. B., Agegian, C. R. (1977). Localized mass mortality of red sea urchin, Strongylocentrotus franciscanus, near Santa Cruz, California. Fish. Bull. U.S. 75: 645-648

Pearse, J. S., Hines, A. H. (1979). Expansion of a Central California kelp forest following the mass mortality of sea urchins. Mar. Biol. 51: 83-91

Peters, E. C. (1993). Diseases of other invertebrate phyla: Porifera, Cnidaria, Ctenophora, Annelida, Echinodermata. In: Couch, J. A., Fournie, J. W. (eds.) Advances in fisheries science. Pathobiology of marine and estuarine organisms. CRC Press, Boca Raton, p. 393-449

Pringle, J. D. (1986). A review of urchin/macro-algal associations with a new synthesis for nearshore, eastern Canadian waters. Monogr. Biol. 4: 191-218

Propp, M. V. (1977). Ecology of the sea urchin Strongylocentrotus droebachiensis in the Barents Sea: metabolism and regulation of abundance. Soviet J. mar. Biol. 3: 27-37

Røv, N., Christie, H., Fredriksen, S., Leinaas, H. P., Lorentsen, S.-H. (1990). Biologisk forundersøkelse i forbindelse med planer om taretråling i Sor-Trøndelag. NINA Oppdragsmelding 52. Norsk Institut for Naturforskning, Oslo

Scheibling, R. E. (1984). Echinoids, epizootics and ecological stability in the rocky subtidal off Nova Scotia, Canada. Helgoländer Meeresunters. 37: 233-242

Scheibling, R. E. (1986). Increased macroalgal abundance following mass mortalities of sea urchins (Strongylocentrotus droebachiensis) along the Atlantic coast of Nova Scotia. Oecologia 68: 186-188

Scheibling, R. E. (1988). Microbial control of sea urchins: Achilles' heel or Pandora's box? In: Burke, R. D., Mladenov, P. V., Lambert, P., Parsley, R. L. (eds.) Echinoderm biology: proceedings of the Sixth International Echinoderm Conference, Victoria. A. A. Balkema, Rotterdam, p. $745-754$

Scheibling, R. E., Raymond, B. G. (1990). Community dynamics on a subtidal cobble bed following mass mortalities of sea urchins. Mar. Ecol. Prog. Ser. 63: 127-145

Scheibling, R. E., Stephenson, R. L. (1984). Mass mortality of Strongylocentrotus droebachiensis (Echinodermata: Echinoidea) off Nova Scotia, Canada. Mar. Biol. 78: 153-164

Sivertsen, K. (1982). Utbredelse og variasjon i kråkebollers nedbeiting av tareskogen på vestkysten av Norge. Nordlandsforskning. Rapport 7/82. Nordlandsforskning, Bodø

Sivertsen, K., Wentzel-Larsen, I (1989). Fangstbare forekomster av kråkeboller. Nordlandsforskning. Rapport $3 / 89$. Nordlandsforskning, Bodø

Sjøtun, K., Fredriksen, S., Lein, T., Rueness, J., Sivertsen, K. (1993). Population studies of Laminaria hyperborea from its northern range of distribution in. Norway. Hydrobiologia 260: 215-221

Skadsheim, A., Rinde, E. (1995). Økologisk kartlegging av tareskogsamfunnet i Froan. NINA Oppdragsmelding (in 
press). Norsk Institut for Naturforskning, Oslo

Skadsheim, A., Rinde, E., Christie, H. (1993\}. Forekomst og endringer i kråkebolletetthet, kråkebolleparasitt og gjenvekst av tareskog langs norskekysten fra Trøndelag til Troms. NINA Oppdragsmelding 258. Norsk Institut for Naturforskning, Oslo

Snedecor, G. W., Cochran, W. G. (1981). Statistical methods, 7 th edn. Iowa State Univ. Press, Ames

Stien, A. (1993). The ecology and epidemiology of Echinomermella matsi (Nematoda), a parasite of the sea urchin Strongylocentrotus droebachiensis. Cand. scient. thesis, Univ. of Oslo

This article was submitted to the editor
Stott, F. C. (1931). The spawning of Echinus esculentus and some changes in gonad composition. J. exp. mar. Biol. Ecol. 8: 133-150

Swan, E. F. (1961). Some observations on the growth rate of sea urchins in the genus Strongylocentrotus. Biol. Bull. mar biol. Lab. Woods Hole 120: 420-427

Vasseur, E. (1952). Geographic variation in Norwegian sea urchins, Strongylocentrotus droebachiensis and S. pallidus. Evolution 6: 87-100

Williams, E. H. Jr, Peters, E. C., Bauer, J., Sullivan, G., Bullis, R. A., Woodley, J., Edbanks, G., Grizzle, J. M., Nusbaum, K. E. (1991). Threat to black sea urchins. Nature 352: 385

Manuscript first received: June 27, 1994

Revised version accepted: November 28, 1994 